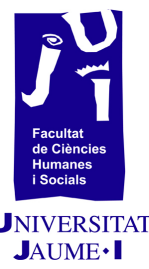

\title{
Analysis of the correlation between self-perceived linguistic competence and language attitudes in the Valencian multilingual context
}


I. Abstract

Language learning, language use and language attitudes are narrowly interrelated concepts, whose significance becomes even more relevant in diglossic settings involving a majority, a minority and a foreign language. This is precisely the fractured linguistic context of the Valencian Community, where the burgeoning role of English in the educational system adds to the asymmetrical bilingual setting in which the autochthonous language is minoritized in its own territory. Therefore, drawing on multilingualism and language attitudes as the theoretical framework, this study provides an interface between both concepts by focusing on the correlation between self-perceived competence and language attitudes in the Valencian multilingual setting by secondary education students.

As part of more extensive research examining the correlation between several variables and language attitudes, this paper builds on the previous findings on language attitudes in Catalan-speaking areas. It analyses the impact of self-assessed competence in both the majority and minority languages (Catalan and Spanish) on language attitudes towards the three languages amongst a sample of $624^{\text {th }}$ year ESO students from the Catalan-speaking area of the Valencian Community. From a quantitative approach, this cross-sectional study presents a statistical analysis of the gathered data, searching bivariate correlations to determine the correlation between both variables. The analysis of the results and the following conclusions highlight the correlation between language proficiency and language attitudes as well as the determinant role of linguistic command to promote balanced language attitudes and to achieve effective bilingualism.

Keywords: language attitudes, self-perceived competence, asymmetrical bilingualism, diglossic context, multilingualism.

\section{Introduction}

The international sociolinguistic landscape has changed dramatically over the last century partly fuelled by the increasing number of multilingual individuals and societies to the extent of multilingualism emerging as an all-pervading phenomenon (Gorter 2006, Auer and Wei 2007, Todeva and Cenoz 2009, Cenoz 2013). Thus, although the number of multilingual individuals and communities overcoming those being proficient in only one language is not a recent occurrence (Cenoz and Genesse 1998, Dewaele 2005, Safont 2007), it was in the middle of the 20th century that it began to catch the attention of researchers and to create a corpus that 
continues to increase (Herdina and Jessner 2002, Gorter 2006,

Pavlenko 2007, De Angelis and Dewaele 2011).

As pointed out by Alcón and Safont $(2013$, cited in Portolés 2015) the growing interest in this phenomenon can be mainly attributed to two different factors: the expanding role of English as a lingua franca and the revitalization of minority languages.

Notwithstanding this fact, despite unequally effective linguistic policies to bolster language revitalization, the evident linguistic imbalance between majority and minority languages and their different official and social status is alarming (Extra and Gorter 2001, Phillipson 2004, 2006, Romaine 2007). Spain, that holds about $50 \%$ of the 20 million speakers of minority languages in the European framework (Lasagabaser 2017), presents a wide context for the study of multilingualism, affective factors and language learning and uses, as it is shown by the numerous studies conducted in the bilingual autonomous communities (Lasagabaster 2000, 2003, 2005a, Pascual 2006, Huguet 2007b, Lasagabaster 2007, Safont 2007, Portolés 2011, 2015, Safont 2015). Nevertheless, this study will focus on the Valencian Community, a highly diglossic setting that had been neglected until a few years ago when authors started to turn their attention to this multilingual context (Safont 2007, Portolés 2011, Nightingale 2012, Portolés 2014, Safont 2015, Nightingale 2016).

As regards the role of English as a Lingua Franca (ELF), as stated by Cenoz and Jessner (2000), although its global pervasiveness is widely assumed, its interface in conjunction with or in opposition to minority languages is contentious (Phillipson and Skutnabb-Kangas 1996, House 2003, Phillipson 2004, Dewey 2007, Portolés 2015). In the case of the Valencian Community, it plays a paramount role in the educational system wherein English is the first and most widespread foreign language.

When dealing with languages, it is essential to adopt a holistic approach since they cannot be isolated from their speakers, nor from the socio-cultural context wherein they are used and wherefrom they stem. Actually, context is credited with a widespread impact on the speakers that will further leverage their attitudes towards other languages and their own. It is against this multilingual background, that the importance of language attitudes emerges. The role of affective factors is paramount in educational contexts in multilingual settings involving a majority, a minority language in process or revitalization and a foreign language (Lasagabaster 2003, 2005a). As it has been widely stated (Dörnyei 1990, Baker 1992, Garrett 2001, Dörnyei 2003, Huguet and González-Riaño 2004, Lasagabaster 2005b), attitudes held towards a language will influence both its learning process and its future use on the part of the learners. Language attitudes are also clearly influenced by the social perception of a language and its use in society (Riley 2007, Todeva 
and Cenoz 2009, Bou 2016), even though these attitudes can be learnt and modified by means of effective language and language-ineducation policies.

However, bilingual and multilingual policies and language attitudes are unfortunately not always in line with scientific and linguistic research. This is the case of the Valencian Community, where effective bilingualism is less widespread than it could be expected in a region in which two languages, Spanish and Catalan, hold co-official status.

\section{The Valencian multilingual context}

The Valencian Community is a highly diglossic context, wherein the majority language (Spanish) coexists with Catalan, the autochthonous minority and minoritized language, in an asymmetrical bilingual setting. In this diglossic frame, a foreign language, English, comes on the scene, thus creating a multilingual context with three languages in contact.

Although the Valencian Community is a bilingual region, in which both languages, Catalan and Spanish, share official status, effective bilingualism is not the norm. If both co-official languages status and social widespread are compared with the linguistic context in other autonomous communities sharing both the same official languages, such as Catalonia or the Balearic Islands, the minority position of Catalan in favour of the dominant language, Spanish, is evident. This linguistic imbalance in the Valencian Community, Catalan being the minority language in its own historical territory has raised increasing interest in recent years (Safont 2007, González-Martínez 2010, Calatayud 2011, Portolés 2014).

The attempts at developing effective bilingualism amongst students resulted in a wide array of linguistic programs, partly influenced by the two linguistic regions in the Community, the predominantly Spanish-speaking and the Catalan-speaking areas. This division, first established by the Statute of Autonomy (Generalitat Valenciana 1982) and adopted by the LUEV one year later (art 6.7), has strongly determined future language and language-in-education policies as well as it has perpetuated linguistic conflict impeding symmetrical bilingualism (Torró 2001, Pascual 2006, Bodoque 2011, Pascual 2011, Arnau and Vila 2013). Furthermore, the fact that the presence of Catalan is unequal through all rungs of the educational ladder does not help promote a cohesive concept of the language nor booster its social status which results in an unsteady disparity in the use of the vernacular language.

Thus, this diglossic context and fractured educational model leads to strong divisions between Spanish and Catalan native speakers, language educational models based on the majority or 
minority language and an unequal command of both the co-official languages according to the specific sociolinguistic features of the students. Consequently, language attitudes are strongly polarized between two linguistic groups, which in turn determine language learning and language use.

This study is set in the Catalan-speaking territories, where two different programmes co-exist in secondary education. The Spanishmedium model, "Programa d'incorporació progressiva» (PIP), wherein Spanish is the main language of instruction and the Catalanbased model, "Programa d'Ensenyament en Valencià» (Valencian Teaching Programme, hereafter PEV), which uses Catalan as the vehicular language.

\section{Objectives}

The current study aims to shed light on the research on language attitudes in the multilingual context of the Valencian community, a sociolinguistic setting generally neglected until the last decades. Following the path initiated by Safont's (2007) and Portolés' studies (2011), who started filling the gap on research in language attitudes in the Valencian Community from a multilingual approach, this study focuses on the impact of self-assessed linguistic competence in both the co-official languages, Spanish and Catalan, on language attitudes towards the three languages present in the curriculum: Catalan, Spanish and English. The variable 'linguistic competence' was selected due to its relevance in previous studies that place it amongst the most definitely agreed upon influential factors on language attitudes (Baker 1992, Janés 2006, Querol and Huguet 2010).

As pointed out by Lasagabaster and Sierra (2009) "the more positive the students' attitudes, the higher their L2 achievement». Thus, taking into account that there is a "bidirectional correlation» between language proficiency and language attitudes (Lasagabaster 2005a, Nightingale 2012, cited in Portolés 2015) we will evaluate students' self-evaluated competence both in the majority and the minority language and its impact on language attitudes. The research question and the consequent hypothesis which will guide the study are as follows:

RQ1: Does students' self-assessed competence in both the coofficial languages have an impact on their attitudes towards the three languages in contact?

$\mathrm{H} 1$ : There is a correlation between students' self-assessed competence in both the co-official languages and their attitudes towards the three languages in contact. 
This is a cross-sectional study which follows a quantitative method, based on the standards of validity, reliability, replicability, generalizability (Brown 1988) to gather the data and analyse the results obtained. According to Brown and Rodgers' (2002) classification, this study is a primary research that contains both a survey research (including the use of questionnaires and Likert scales) and a descriptive statistical research. The obtained data were analysed using the Statistical Package for the Social Sciences (SPSS).

\section{Participants}

The sample was constituted by $624^{\text {th }}$-year ESO students (15-16 years old) from "Les Alfàbegues» state high school in Bétera, a medium-sized village located in a predominantly Catalan-speaking area. This is a heterogeneous group and the pupils study any of the two $4^{\text {th }}$-year ESO branches: Academic and Applied Education, which will gear them to Batxillerat or Vocational Training studies respectively, in both the linguistic programmes offered in the school, the Valencian-based (PEP) and the Spanish-based (PIP) models. This duality regarding the linguistic models was one of the reasons to select this as the setting for our study since it was the only institution of secondary education in Bétera where the variable linguistic model could be observed.

Regarding the features of the sample, their distribution according to gender is quite balanced, $51.61 \%$ of the respondents being female and $48.39 \%$ male. Nevertheless, it is striking to notice that although there is maintenance in the percentage of students following the Catalan-based model both in primary and secondary school (57.38\%), the exclusive or nearly exclusive use of the minority language only represents $9.62 \%$ of social interactions with friends at school, a percentage that drops when talking to friends outside school (1.9\%). In fact, a majority of students reported using only or mostly Spanish at home, In social interactions with relativea and strangers, as well as with their peers and friends, inside $(67.31 \%)$ and outside school (76.92\%). These data are in line with the language students self-identify, which is mainly Spanish (61.29\%), followed by Catalan (19.35\%) and both (12.9\%).

As for the learning of the foreign language, the average age they started learning English was 5.74 years old. It is significant to observe that averagely, students began speaking Spanish earlier (2.85 years old) than they started learning Catalan (4.45). 


\section{Research instruments}

The research instruments used to collect and analyse the data involved four questionnaires filled in by the students which included a sociolinguistic survey, a self-assessment of their linguistic competence in both the co-official languages, and sets of questions to evaluate their language use and their attitudes towards the 3 languages in contact. These questionnaires had been successfully used in previous research in bilingual and multilingual contexts both in the Catalan-speaking regions and abroad (Huguet and Llurda 2001, Laoire 2007, Lasagabaster 2007, Safont 2007, Portolés 2011).

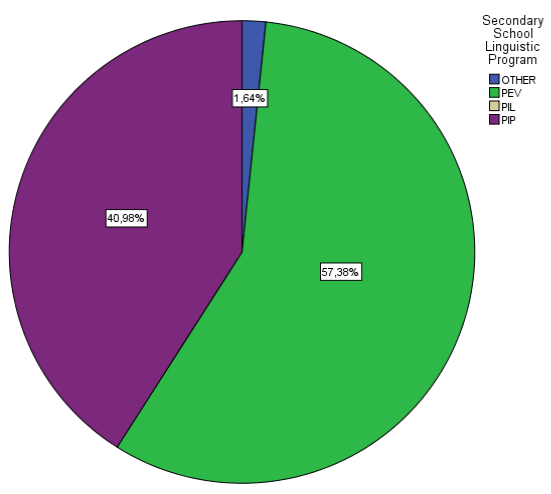

Figure 1. Gender and primary and secondary linguistic programs

The first instrument (sociolinguistic survey) consists of 24 questions which mainly gather data about students' linguistic background, linguistic educational program, language transmission, familiar geographical origin and parent's educational and socioprofessional status. The self-assessment questionnaire to gauge student's self-perceived competence both in Spanish and Catalan has been adapted from previous questionnaires that analysed language attitudes in the Valencian Community (Safont 2007, Portolés 2011). It consists of 8 questions, 4 per language to assess students' own perception of their language competence in every skill (listening, reading, speaking and writing). It uses a Likert scale from 1 to 10, in contrast with the 5-Likert rating questionnaire to measure their language attitudes towards the three languages in contact (questionnaire 3). To analyse the student's use of the two co-official languages, the third questionnaire consists of 19 multiple choice questions which were adapted and designed to gather data on several social interactions and situations wherein both languages are used. Finally, the last questionnaire gathers data on language attitudes towards Spanish, Catalan and English. To this aim, it includes the same 10 statements for each of the three languages, 30 in total, to be measured by means of a 5-Likert scale.

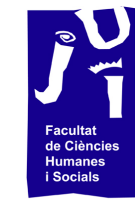

UNIVERSITAT JAUME $\mathbf{I}$ 
Before analysing the correlation between self-assessed linguistic competence and language attitudes, I analysed and compared student's self-perceived competence in both the co-official languages.

The first graph displays the self-perceived linguistic competence in the majority language, wherein both the mean and the median are significantly higher (9.13 and 9.50) as opposed to the linguistic competence in Catalan, showed in the second graph, where the mean and the median drop to 7.87 and 7.90 respectively.

It is also noticeable the difference between the ranges in the majority and the minority languages. Thus, the general range in selfperceived linguistic competence in Catalan is much wider (5.75) than the general range in the majority language, 4.75. This difference becomes even more evident when we eliminate the isolated data in both languages, in which case the range of self-assessed competence in Spanish drops to 2.25 whereas in the minority language the range reaches 4.50 .

According to the previous analysis, it can be deduced that students perceive to possess a higher command of the majority language in contrast to their self-perceived lower proficiency in the minority language. Furthermore, it is noticeable that participants' values of self-perceived competence in Catalan are more spread out and therefore there is a greater variability amongst students' responses.

This great variability in the data regarding self-assessed linguistic competence in Catalan led me to analyse the distribution of linguistic competence in the minority language in deeper detail to find out the segment of the sample where we can find this disparity.

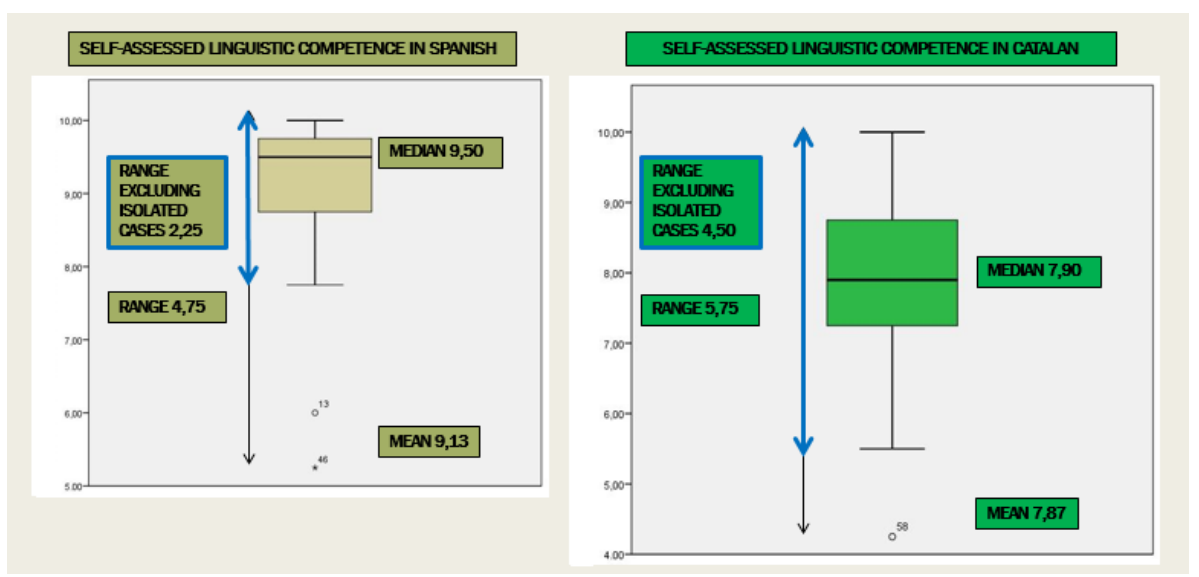

Figure 2. Self-assessed linguistic competences distribution 
The graph below shows the analysis of the distribution of students' language attitudes according to their mother tongue, Spanish, Catalan or self-perceived bilinguals in both languages.

It can be observed that, as could have been expected, the wider variability in self-perceived linguistic competence in Catalan can be found amongst students whose mother tongue is Spanish. In fact, except for the isolated data, the global range coincides with the range of Spanish-native speakers. On the contrary, the range is lower and self-perceived linguistic competence in Catalan values are higher amongst those students who have Catalan as their only or at least as one of their mother tongues.

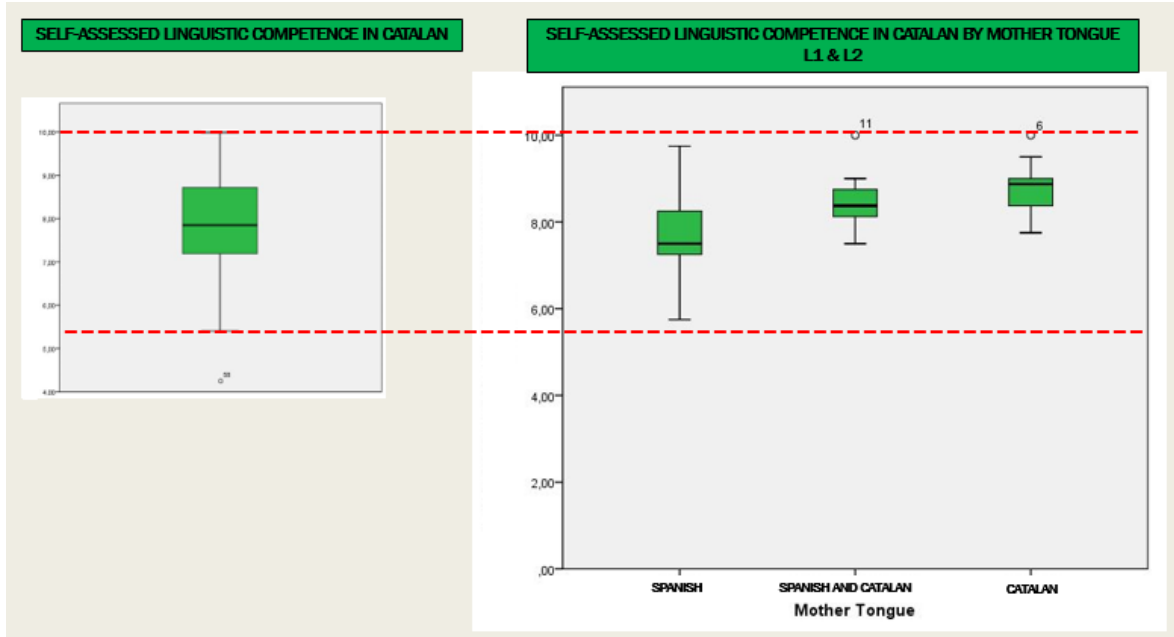

Figure 3. Distribution of self-assessed competence in Catalan by mother tongue

After having observed the students' self-assessed competence in both languages, I analysed the data statistically regarding language attitudes towards the three languages examined in this study, obtaining a mean of 4.06 (L1), 3.74 (L3) and 3 (L2) as shown in Table 1. The results show that students hold more polarized attitudes towards L2 (Catalan), their variance being 0.92; as opposed to 0.54 in Spanish (L1) and 0.60 in English (L3). This polarization in attitude is especially noticeable in the segment of respondents that hold much less favourable attitudes towards Catalan, as reflected in the fact that the $25^{\text {th }}$ percentile regarding $L 2$ is further from the mean than the corresponding percentiles regarding the other analysed languages. Furthermore, according to the rank analysis it can also be deduced that the respondents display a wider range of attitudes towards the minority language. 
Table 1. Attitudes towards languages

\begin{tabular}{|l|l|l|l|l|l|l|}
\hline & $\begin{array}{l}\text { Mea } \\
\mathrm{n}\end{array}$ & $\begin{array}{l}\text { Percentile } \\
25\end{array}$ & $\begin{array}{l}\text { Media } \\
\mathrm{n}\end{array}$ & $\begin{array}{l}\text { Percentile } \\
75\end{array}$ & $\begin{array}{l}\text { Rang } \\
\mathrm{e}\end{array}$ & $\begin{array}{l}\text { Varianc } \\
\mathrm{e}\end{array}$ \\
\hline $\begin{array}{l}\text { ATTITUDES } \\
\text { TOWARDS } \\
\text { CATALAN }\end{array}$ & 3.03 & 2.40 & 2.90 & 3.70 & 3.79 & .86 \\
\hline $\begin{array}{l}\text { ATTITUDES } \\
\text { TOWARDS } \\
\text { SPANISH }\end{array}$ & 4.05 & 3.50 & 4.10 & 4.60 & 3.00 & .53 \\
\hline $\begin{array}{l}\text { ATTITUDES } \\
\text { TOWARDS } \\
\text { ENGLISH }\end{array}$ & 3.75 & 3.30 & 3.70 & 4.20 & 3.20 & .52 \\
\hline
\end{tabular}

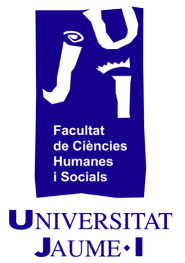

Thus, as depicted in Figure 4, more positive attitudes were displayed towards Spanish and less favourable ones towards Catalan. It is remarkable that attitudes towards the foreign language, although still scored lower than those towards the majority language, were still more favourable than attitudes towards Catalan. In fact Catalan is the language towards which the students hold the least positive attitudes.

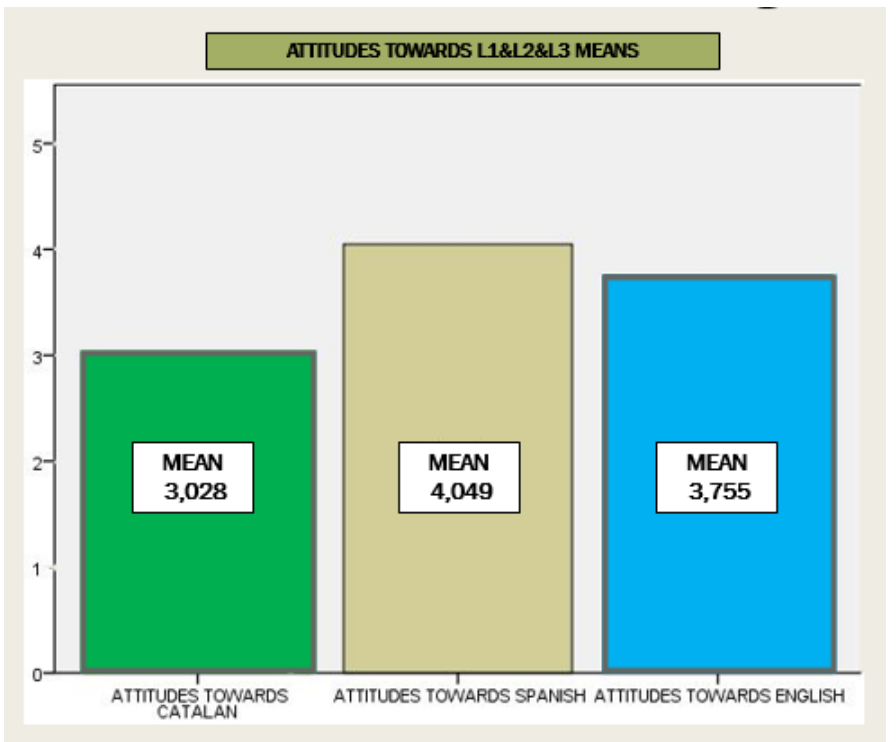

Figure 4. Attitudes towards L1, L2 and L3 means

Once I had studied students' self-perceived linguistic competence in both the co-official language, their distribution according to mother tongue and their attitudes means towards the three languages involved, I analysed the proposed research question that guided this study. To answer it I had to compare 6 different combinations which were the result of determining the influence of the self-perceived competences in L1 and L2 in each of the three languages object of study.

I consider that the verification of at least 4 of these combinations between the three languages in contact and the self- 
assessed competence in the two co-official languages will result in the confirmation of the hypothesis.

To test the 6 combinations I carried out a bivariate correlation to determine the linear relationship between the variables, comparing them in pairs, where the obtained Pearson correlation coefficients indicate the strength of the linear relationships between the pairs (Table 2. Correlations attitudes - self-assessed competences). The pairs whose correlations have significance in the level 0.01 are highlighted in dark colours, whereas those in light colours, display significance in the level 0.05. 5 out of the 6 correlations tested were verified; thus being 3 direct correlations (coloured in blue) and 1 indirect correlation (coloured in red) established. Only one of the analysed pairs was assessed as no correlated (no coloured). It is significant that self-assessed linguistic competence in one of the co-official languages is directly correlated to attitudes towards this language but indirectly correlated to attitudes towards the other co-official language. These results reflect the linguistic conflict between both the majority and the minority languages.

Table 2. Correlations attitudes - self-assessed competences

\begin{tabular}{|c|c|c|c|c|}
\hline & & $\begin{array}{l}\text { ATTITUDES } \\
\text { TOWARDS } \\
\text { CATALAN }\end{array}$ & $\begin{array}{c}\text { ATTITUDES } \\
\text { TOWARDS } \\
\text { SPANISH }\end{array}$ & $\begin{array}{c}\text { ATTITUDES } \\
\text { TOWARDS } \\
\text { ENGLISH }\end{array}$ \\
\hline \multirow{2}{*}{$\begin{array}{l}\text { Self-assessment of } \\
\text { linguistic } \\
\text { competence in } \\
\text { Catalan }\end{array}$} & $\begin{array}{c}\text { Pearson } \\
\text { Correlation }\end{array}$ & $629^{* *}$ &,$- 370^{* *}$ &,- 051 \\
\hline & $\begin{array}{c}\text { Sig. } \\
\text { (bilateral) }\end{array}$ & ,000 & ,003 & 693 \\
\hline \multirow{2}{*}{$\begin{array}{l}\text { Self-assessment of } \\
\text { linguistic } \\
\text { competence in } \\
\text { Spanish }\end{array}$} & $\begin{array}{c}\text { Pearson } \\
\text { Correlation }\end{array}$ &,$- 280^{*}$ &, $341^{* *}$ &, $345^{* *}$ \\
\hline & $\begin{array}{c}\text { Sig. } \\
\text { (bilateral) }\end{array}$ & 027 & ,007 & ,006 \\
\hline
\end{tabular}

The following summary (Table 3 ) shows the existing correlations, their direction, and significance level.

Table 3. Summary of correlations H3 secondary hypotheses

\begin{tabular}{|l|l|l|l|}
\hline & $\begin{array}{l}\text { ATTITUDES } \\
\text { TOWARDS } \\
\text { CATALAN }\end{array}$ & $\begin{array}{l}\text { ATTITUDES } \\
\text { TOWARUDSS } \\
\text { TOWARDS }\end{array}$ \\
\hline $\begin{array}{l}\text { Competence in } \\
\text { Catalan }\end{array}$ & $\begin{array}{l}\text { Direct correlation } \\
\text { Level } 0.01\end{array}$ & $\begin{array}{l}\text { Indirect Correlation } \\
\text { Level } 0.01\end{array}$ & No correlation \\
\hline $\begin{array}{l}\text { Competence in } \\
\text { Spanish }\end{array}$ & $\begin{array}{l}\text { Indirect Correlation } \\
\text { Level } 0.05\end{array}$ & $\begin{array}{l}\text { Direct correlation } \\
\text { Level } 0.01\end{array}$ & $\begin{array}{l}\text { Direct correlation } \\
\text { Level } 0.01\end{array}$ \\
\hline
\end{tabular}

Hence, it can be concluded that there is a correlation between the self-assessed competence in both the majority and the minority 
languages and the student's attitudes towards both the co-official languages. The results also confirmed the correlation between the self-assessed competence in Spanish and the students' attitudes towards the foreign language. The non-verification of the correlation between the self-perceived competence in Catalan and the students' attitudes towards English, confirmed its null hypothesis.

After confirming a correlation in 5 out of the 6 possible variable combinations, we can conclude that the posed hypothesis is confirmed, and therefore "There is a correlation between the selfassessed competence in L1 and L2 and the students' attitudes towards the analysed languages», wherefrom the following conclusion can be drawn.

There are strong positive correlations between self-assessed competence in each of the co-official languages and attitudes towards these. Thus, a higher self-evaluated competence in Catalan correlates to more positive attitudes towards the minority language and in the same vein there is a powerful association between higher competence in Spanish and more favourable attitudes towards the majority language. On the contrary, linguistic competence and attitudes between the two co-official languages are negatively correlated. Regarding the foreign language, there is a positive correlation between competence in Spanish and attitudes towards English, although this correlation is smaller than previous linear relationships.

From the previous results we can conclude that there is a correlation between self-perceived competence and language attitudes, thus confirming our hypothesis.

\section{Conclusions}

From the analysis and discussion of the results of our study in light of previous research (Lasagabaster 2005a, Huguet 2007a, Lasagabaster 2007, Safont 2007, Portolés 2011, 2015, Lasagabaser 2017, Lasagabaster 2017), several conclusions can be drawn as regards both language policies and future research. Our findings confirm our hypothesis, and therefore, we can corroborate that there is a correlation between self-assessed linguistic competence and the students' attitudes towards the three analysed languages. Thus, the variable self-assessed competence in both the co-official languages yielded significant differences on the attitudes towards the three languages in contact at the same time that proved to have a bearing on students' linguistic attitudes.

As it had been stated in the introduction, there is bidirectional relationship between language attitudes and language proficiency (Lasagabaster 2003)(cited in Portolés 2015). This is confirmed by our results that observe a direct correlation between self-assessed 
competence in Catalan and more favourable attitudes towards the minority language. Similarly, students' positive attitudes towards Spanish are also directly correlated with referring higher competences in the majority language. These findings coincide with the conclusions of previous studies in bilingual and multilingual contexts (Lasagabaster 2003, 2005a, Laugharne 2007, Querol and Huguet 2010, Portolés 2011, Madariaga, Huguet, and Janés 2016).

As we had expected according to previous research (Baker 1992, Lasagabaster 2005b, Huguet 2007a, Huguet, Laprestra, and Madariaga 2008, Lasagabaser 2017, Lasagabaster 2017), the findings yielded notable disparities on language attitudes towards the majority and the minority languages, in this case between the Spanish-speaking and the Catalan-speaking groups. It is important to remark that the attitudes of self-perceived bilinguals tend to converge with those of the students whose mother tongue is only Catalan. Moreover, the study also showed an inverse correlation between respondents' mother tongue and their attitudes towards the other co-official language, be it Catalan or Spanish. Thus, attitudes towards the majority and the minority languages were skewed towards the positive pole or the opposite of the attitudinal continuum according to the positive or negative attitudes displayed towards Catalan or Spanish.

As for the limitations of the study we should refer to the sample, which is one of the most commonly shortcomings encountered in the field of educational research. In fact, the size and localization of the sample does not automatically make the findings fully extensible to the rest of the Valencian Community. For this reason, these constraints on generalizability require additional research to be conducted with extended samples covering an area as extended as possible, to amend possible shortcomings associated with crosssectional studies, longitudinal studies would also be advisable.

The considerable differences in language attitudes towards the three languages present in the curriculum lead us to consider the need of redesigning language and language-in-education policies that allow every student to achieve the same level of bilingualism and to foster positive attitudes towards the three languages.

Further research in this field is essential since drawing a map on language attitudes amongst the students allows to investigate the causes and shift or minimize their negative impact. Affective factors are a paramount element in determining the future downward trend in the use of a minority language since language use and vitality are strongly influenced by the speakers' perception of the languages in contact (Baker 1992). Thus, reverting a negative attitude towards a language not only leads to an increase in the motivation to learn it and use it, but also on the attainment of a higher linguistic command 
which paves the path, in conjunction with other factors, to the possible revitalization of its social use.

It is common knowledge that the official status of a language does not guarantee its survival, nor its inclusion as a subject in the educational system implies a wider use. Therefore, it is essential to promote effective language and language-in-education policies to try to balance the status of the majority and the minority languages with the aim of achieving a balanced bilingualism that boosts positive language attitudes towards the three languages involved.

\section{References}

Alcón, Eva, and Maria Pilar Safont. 2013. «English and multilingualism.» In Encyclopaedia of Applied Linguistics, edited by Carol A. Chapelle, 3883-3888. New York: Wiley \& Sons.

De Angelis, Gessica, and Jean-Marc Dewaele. 2011. New trends in crosslinguistic influence and multilingualism research. Clevedon: Multilingual Matters.

Arnau, Joaquim, and F. Xavier Vila. 2013. "Language in education policies in the Catalan language area." In Reviving Catalan at school Challenges and instructional approaches edited by Joaquim Arnau, 1-28. Bristol: Multilingual Matters.

Auer, Peter, and Li Wei, eds. 2007. Handbook of multilingualism and multilingual communication. Vol. 5. Berlin: Mouton de Gruyter.

Baker, Colin. 1992. Attitudes and language. Clevedon: Multilingual Matters.

Bodoque, Anselm. 2011. "El model valencià de política lingüística.» Revista de Llengua i Dret 56: 143-171.

Bou, Mireia. 2016. "Les actituds lingüístiques i la tria lingüística en les comunicacions formals de nous moviments socials a Catalunya.» Revista de Llengua i Dret 66: 38-61.

Brown, James D. 1988. Understanding research in second language lerning: A teacher's guide to statistics and research design. Cambridge: Cambridge University Press.

Brown, James D., and Theodore S. Rodgers. 2002. Doing second language research: An introduction to the theory and practice of second language research for graduate/master's students in TESOL and applied linguistics, and others. Oxford: Oxford University Press.

Calatayud, Víctor A. 2011. "Análisis de la realidad sociolingüística del valenciano.» Papers: revista de sociología 96 (2): 501-514. 
Cenoz, Jasone. 2013. "Defining multilingualism.» Annual Review of Applied Linguistics 33: 3-18.

Cenoz, Jasone, and Fred Genesse, eds. 1998. Beyond bilingualism: Multilingualism and multilingual education. Vol. 110. Clevedon: Multilingual Matters.

Cenoz, Jasone, and Ulrike Jessner, eds. 2000. English in Europe: The acquisition of a third language. Vol. 19. Clevedon: Multilingual Matters.

Dewaele, Jean-Marc. 2005. "Sociodemographic, psychological and politico-cultural correlates in Flemish students' attitudes towards French and English.» Journal of Multilingual and Multicultural Development 26: 118-137.

Dewey, Martin. 2007. "English as a lingua franca and globalization: an interconnected perspective." International Journal of Applied Linguistics 17 (3): 332.

Dörnyei, Zoltdn. 1990. "Conceptualizing motivation in foreignlanguage learning." Language Learning 40 (1): 45-78.

Dörnyei, Zoltdn. 2003. "Attitudes, orientations and motivations in language learning: Advances in theory, research and applications.» Language Learning 53 (1): 3-32.

Extra, Guus, and Durk Gorter, eds. 2001. The other languages of Europe: Demographic, sociolinguistic, and educational perspectives. Clevedon: Multilingual Matters.

Garrett, Peter. 2001. "Language attitudes and sociolinguistics.» Journal of Sociolinguistics 5 (4): 626-631.

Generalitat Valenciana. 1982. Estatut d'Autonomia de la Comunitat Valenciana.

Generalitat Valenciana. 1983. Llei d'Ús i Ensenyament del Valencià. Llei 4/1983, 23 de novembre.

González-Martínez, Juan L. 2010. «Actitudes lingüísticas en una comunidad rural: Els Ports (Castellón). Datos de un cuestionario sociolingüístico.» Cultura, Lenguaje y Representación 8: 75-95.

Gorter, Durk, ed. 2006. Linguistic landscape: A new approach to multilingualism. Clevedon: Multilingual Matters.

Herdina, Philip, and Ulrike Jessner. 2002. A dynamic model of multilingualism: Perspectives of change in psycholinguistics. Clevedon: Multilingual Matters.

House, Juliane. 2003. «English as a lingua franca: A threat to multilingualism?» Journal of Sociolinguistics 7 (4): 556-578. 
Huguet, Ángel. 2007a. "Language use and language attitudes in Catalonia.» In Multilingualism in European bilingual contexts: Language use and attitudes, edited by David Lasagabaster and Ángel Huget, 17-39. Clevedon: Multilingual Matters.

Huguet, Ángel. 2007b. «Minority languages and curriculum: The case of Spain.» Language, Culture and Curriculum 20 (1): 70-86.

Huguet, Ángel, and Xosé A. González-Riaño. 2004. Actitudes lingüísticas, lengua familiar y enseñanza de la lengua minoritaria. Barcelona: Horsori.

Huguet, Ángel, Cecilio Laprestra, and José M. Madariaga. 2008. «A study on language attitudes towards regional and foreign languages by school children in Aragon, Spain." International Journal of Multilingualism 5 (4): 275-293.

Huguet, Ángel, and Enric Llurda. 2001. "Language attitudes of school children in two Catalan/Spanish bilingual communities.» International Journal of Bilingual Education and Bilingualism 4 (4): 267-282.

Janés, Judit. 2006. "Las actitudes hacia las lenguas y el aprendizaje lingüístico.» Revista Interuniversitaria de Formación del Profesorado 20 (56): 117-132.

Laoire, Muiris Ó. 2007. "Language use and language attitudes in Ireland.» In Multilingualism in Europeanbilingual contexts: Language useand attitudes, edited by David Lasagabaster and Ángel Huguet. Clevedon: Multilingual Matters.

Lasagabaser, David. 2017. "Language Learning Motivation and Language Attitudes in Multilingual Spain from an International Perspective.» Modern Language Journal 101: 583-596.

Lasagabaster, David. 2000. "Three languages and three linguistic models in the Basque educational system." In Bilingual Education and Bilingualism, edited by Jasone Cenoz and Ulrike Jessner, 179-197. Clevedon Multilingual Matters.

Lasagabaster, David. 2003. Trilingüïsmo en la enseñanza. Actitudes hacia la lengua minoritaria, la mayoritaria y la extranjera. Lleida: Editorial Milenio.

Lasagabaster, David. 2005a. "Attitudes towards Basque, Spanish and English: An analysis of the most influential variables." Journal of Multilingual and Multicultural Development 26 (4): 296-316.

Lasagabaster, David. 2005b. "La presencia de tres lenguas en el currículo: Multilingüismo en los contextos canadiense y español.» Revista de Educación 337: 405-426. 
Lasagabaster, David. 2007. "Language use and Language attitudes in the Basque Country." In Multilingualism in European bilingual contexts: Language use and attitudes, edited by David Lasagabaster and Ángel Huguet. Clevedon: Multilingual Matters.

Lasagabaster, David. 2017. "Language Learning Motivation and Language Attitudes in Multilingual Spain from an International Perspective.» Modern Language Journal 101: 583-596.

Lasagabaster, David, and Juan Manuel Sierra. 2009. «Immersion and CLIL in English: more differences than similarities.» ELT Journal 64 (4): 367-375.

Laugharne, Janet. 2007. "Language use and language attitudes in Wales.» In Multilingualism in European bilingual contexts: Language use and attitudes, edited by David Lasagabaster and Ángel Huguet, 208-233. Clevedon: Multilingual Matters.

Madariaga, José M., Ángela Huguet, and Judit Janés. 2016. «Language attitudes in Catalan multilingual classrooms: educational implications.» Language and Intercultural Communication 16 (2): 216-234.

Nightingale, Richard. 2012. Bridging the gap between the internal and the external: The effect of sociocultural factors in adolescent learners' attitudes towards English. Saarbrücken: Lambert Academic Publising.

Nightingale, Richard. 2016. "The effect of out-of-school media contact on language attitudes in multilingual adolescents: A complex psycho-sociolinguistic system.» PhD dissertation. Castelló de la Plana: Universitat Jaume I.

Pascual, Vicent. 2006. El tractament de les llengües en un model d'educació plurilingüe per al sistema educatiu valencià. València: Conselleria de Cultura, Educació i Esport.

Pascual, Vicent. 2011. L'escola valenciana. Un model d'educació plurilingüe $i$ intercultural per al sistema educatiu valencià. Generalitat Valenciana. València: Conselleria de Cultura, Educació i Esport.

Pavlenko, Aneta. 2007. Emotions and multilingualism. Cambridge: Cambridge University Press.

Phillipson, Robert. 2004. English-only Europe? Challenging language policy. London: Routledge.

Phillipson, Robert. 2006. Language policy and linguistic imperialism. An introduction to language policy: Theory and method. Oxford: Blackwell Publishing. 
Phillipson, Robert, and Tove Skutnabb-Kangas. 1996. "English only worldwide or language ecology?» TESOL Quarterly 30 (3): 429452.

Portolés, Laura. 2011. A multilingual portrait of language attitudes in higher education. Saarbrücken: VDM Verlag.

Portolés, Laura. 2014. "Analysing prospective teachers' attitudes towards three languages in two different sociolinguistic and educational settings." In Teaching and learning in multilingual contexts: sociolinguistic and educational perspectives, edited by Agnieszka Otwinowska and Gessica De Angelis, 50-75. Clevedon: Multilingual Matters.

Portolés, Laura. 2015. Multilingualism and very young learners: An analysis of pragmatic awareness and language attitudes. Berlin: Walter de Gruyter.

Querol, Mónica, and Ángel Huguet. 2010. «Conocimiento lingüístico y actitudes lingüísticas. Un estudio sobre sus relaciones en el alumnado de origen inmigrante en Cataluña.» Segundas Lenguas e Inmigración 3: 61-79.

Riley, Philip. 2007. Language, culture and identity: An ethnolinguistic perspective. London: Continuum.

Romaine, Suzanne. 2007. "The impact of language policy on endangered languages." In Democracy and human rights in multicultural societies, edited by Paul de Guchteneire and Matthias Koenig, 217-236. London: Routledge.

Safont, María Pilar. 2007. "Language use and Language attitudes in the Valencian Community." In Multilingualism in European bilingual contexts: Language use and attitudes, edited by David Lasagabaster and Ángel Huguet, 90-116. Clevedon: Multilingual Matters.

Safont, María Pilar. 2015. "The promotion of multilingualism in a Catalan-speaking area. Familial challenges in the Valencian Community.» In The Multilingual Challenge: Cross-Disciplinary Perspectives, edited by Ulrike Jessner and Claire J. Kramsch, 3959. Berlin: Walter de Gruyter.

Todeva, Elka, and Jasone Cenoz, eds. 2009. The multiple realities of multilingualism: Personal narratives and researchers' perspectives. Berlin: Walter de Gruyter.

Torró, Tudi. 2001. «El Català a l'escola del País Valencià: dades i reflexions.» Treballs de Sociolingüística Catalana 20: 193-208. 